\title{
SOCIAL ENTREPRENEURSHIP AND ITS IMPACT ON SOCIETY : SPECIAL SOCIAL-ENTREPRENEURS @HIGHER EDUCATION PROGRAMME IN MALAYSIA
}

\author{
Anees Janee Ali, Jamshed Khalid, and Mass Hareeza Ali, and Razleena Razali \\ Universiti Sains Malaysia, Malaysia \\ Universiti Putra Malaysia, Malaysia \\ Universiti Malaysia Perlis, Malaysia \\ aneesali15@yahoo.com
}

\begin{abstract}
Social entrepreneurship is defined as activities created by an innovative social value to achieve societal needs and financial sustainability. It is a business concept that involve conducting business that does not emphasis much on profit but for the benefit of mankind. Special Social Entrepreneur @Higher Education (SSEHE) is a programme mastered by Universiti Putra Malaysia (UPM) that collaborated with four other universities in Malaysia. The aim of SSEHE is to get handicapped youths to get together and follow talks and discussion in order to create awareness on how they can stand on their own to make a living. The main objectives of SSEHE are transforming the mindset of the disabled youths that they can be independent by involving in entrepreneurial activities, introducing the basic entrepreneurial knowledge to the disabled youths, opening job opportunities to the disabled youths and helping the disabled youths to start and/or expand their business. SSEHE has high hope to continue this programme in the future so that disabled youths are aware that they can use their skills to make a living for themselves and their loved ones.
\end{abstract}

Keyword : Social, Entrepreneurship, SSEHE

\section{UNDERSTANDING OF SOCIAL ENTREPRENEURSHIP}

In recent years social entrepreneurship has gain increasing attention from academic and business world. One of an emergence subdiscipline within entrepreneurship field, social entrepreneurship involves the recognition, evaluation, and exploitation of opportunities that result in social value which is the basic and long-standing needs of society as opposed to personal or shareholder wealth (Austin, Stevenson and Wei-Skillern, 2006). Started in 1980, the social entrepreneurship concept was one of the ideas to encourage social entrepreneurship by providing funds for social missions worldwide. And in 1997, this concept had been carried into academia field by Jed Emerson and Stephen Thake. The idea of social entrepreneurship flourish worldwide by Muhammad Yunus's winnings on the 2006 Nobel Peace Prize of Grameen Bank, the micro credit enterprise concept to develop a better nation economic and social growth in Bangladesh.

\section{DEFINITIONS OF SOCIAL ENTREPRENEUR}

There are numerous definitions of social entrepreneurship suggested by scholars since its being founded by Bill Drayton who started Ashoka in the year 1980, the organization that encourage social entrepreneurship by providing funds for social missions worldwide. The term social refers to the specific tasks which is orientation towards a common good and the claim to impact on societal problems. Shane and Venkataraman (2000) defined the term entrepreneurship as the identification, evaluation, and exploitation of opportunities. Meanwhile, Ricketts (2008) defined entrepreneurship as strategy, innovation, and responsible risk taking.

Therefore, social entrepreneurship is defined as activities created by an innovative social value to achieve societal needs and financial sustainability (Austin et. al., 2006: Mair and Mart'I, 2006: Alter, 2007). Additionally, Austin et al. (2006) distinguished between two types of entrepreneurship; commercial and social entrepreneurship. commercial entrepreneurship represents the identification, evaluation, and exploitation of opportunities that result in profits. In contrast, social entrepreneurship refers to the identification, evaluation, and exploitation of opportunities that result in social value. More formally, Austin et al. (2006) defined social entrepreneurship as innovative, social value creating activity that can occur within or across the nonprofit, business, or government sectors. According to Robert and Woods (2005), social entrepreneurship plays an important role to connect the business and social action. Consequently, the Center for the Advancement of Social Entrepreneurship (CASE) of Duke University's Fuqua School of Business in the United State defined social entrepreneurship as the process of 
recognizing and resourcefully pursuing opportunities to create social value with the innovative method. Social entrepreneurs are innovative, resourceful, and result-oriented, who draw upon the best thinking in both the business and nonprofit worlds to develop strategies that maximize social impact. This is supported by Carraher and Welsh (2015) that conclude social entrepreneurship is a process that involve innovation and resources combination in opportunities seeking that aims to solve social problem and needs.

\section{BENEFITS OF SOCIAL ENTREPRENEURSHIP TO SOCIETY}

Social entrepreneurship allows people to achieve a better quality of life. According to Barki et al., (2015), social entrepreneurship is created to reduce vulnerabilities and seeking and social equalities worldwide. The existence of social entrepreneurship is to ensure that the solutions to social problems such as such as poverty, hunger, natural disasters, war, drugs, people with disabilities, youth, women, pollution and so on can be solved as well as adding value to society. Thake and Zadek (1997) mentioned social entrepreneurship have become an essential goal to achieve a higher quality of life especially for people with disabilities.

Social entrepreneurship is an exciting new area to explore and it provides multiple benefits to the society. Based on the several literature review of social entrepreneurship research, the benefits identified are as follows:

- $\quad$ New Job Creation (OECD, 2003b; Roberts and Woods, 2005; British Council Malaysia, 2019)

Social entrepreneurship creates job opportunities and resolve social and economic problem. In the UK, the social entrepreneurship has been recognized as beneficial strategy for revitalizing communities who are in needs by improving the skills of the unemployed and facilitating their return to work and generating additional jobs. In Malaysia, social entrepreneurship activities provide higher job creation opportunities. Job creation has increased between 2017 and 2018, by 23 per cent for full-time employees and by 33 per cent for part-time staff.

- $\quad$ Foster Innovation (Jeremy et al., 2009)

Social entrepreneurship is a strategic platform to develop innovation that can be solution to social, economic, environmental problems. Engaging in the process of continuous innovation, adaptation, and learning will level up the ability of entrepreneurs to adapt with the market's needs. Also, Jeremy et al., (2009) mention that social entrepreneurship activities contribute to creation of new social value to solve unmet social needs which create innovative process in which opportunities are exploited through bringing together a unique package of resources in the context of a non-profit or public sector organization.

- $\quad$ Reduce National Poverty (M. Yunus et. al., 2010; Si et. al., 2015)

Numerous scholars have suggested that social entrepreneurship allows reduction in nation poverty level. For instance, Grameen Bank of Bangladesh (one social enterprise) has been successful in implementing micro-credit scheme for poor women out from poverty. This is supported by evidence in a case study by Si et. al. (2015), China' level of poverty has been reducing due to social entrepreneurship and innovation course in the nation. Similarly, in Malaysia, Saiful, 2012: Zahra et al., 2008: Adib et al., 2014 mentioned that social entrepreneurship is one of economic strategy to eliminate poverty level of nation.

- $\quad$ Enhance Qualities of Life (Barki et al., 2015; S.T. Certo and T. Miller, 2008; Zahra et. al., 2008; Thake and Zadek, 1997)

Social entrepreneurship allows people to achieve a better quality of life. According to Barki et al., (2015), social Entrepreneurship created to reduce vulnerabilities and seeking and social equalities worldwide. The existence of social entrepreneurship is to ensure that the solutions to social problems such as such as poverty, hunger, natural disasters, war, drugs, people with disabilities, youth, women, pollution and so on can be solved as well as add value to society. Thake and Zadek (1997) mentioned social entrepreneurship have become an essential goal to achieve a higher quality of life especially for people with disabilities.

\section{SOCIAL ENTREPRENEURSHIP AMONG PEOPLE WITH DISABILITIES}

Social entrepreneurship has been gaining growing attention as a potential platform for people with disabilities for being employed or be the entrepreneur themselves. As mentioned earlier by Thake and Zadek (1997), social entrepreneurship has become an essential goal for people with disabilities to achieve a better quality of life. The impacts on people with disabilities are as follows: 
- Increase Employment Rate (S.L. Khoo et. al., 2013; Blanck et. al., 2002; Blanck et. al., 2000) According to S.L. Khoo et. al. (2013) getting employed and entering into job market are challenging for people with disabilities although they have sufficient qualification in the field. The social entrepreneurship activities offer opportunity to achieve gainful employment (Blanck et. al., 2002; Blanck et. al., 2000). For example, Arduin is a Dutch organization that provides services and supports in living, work and/or daily activities for about 800 people with intellectual disability. This organization aims to discover and explore the potentials of people with disabilities.

- Opportunities for Charitable Contribution (Montgomery et al., 2012)

The participation of people with disabilities in social entrepreneurship allow them to contribute to society especially in education or charitable contributions that can solve social problem. This is supported by Montgomery et al. (2012) who suggest that social entrepreneurship creates links between organizations and stimulates collaboration and community-building across the boundaries of different sectors.

- Increase Self- Reliance (Reid A., 2004; Shaw E. and Carter S., 2007; and Zahra S.A et. al., 2009) People with disabilities may be uniquely positioned to become social entrepreneurs due to their discrimination experienced in life (Reid A. 2004). According to Shaw E. and Carter S. (2007) and Zahra S.A (2009) throughout the entrepreneurial process, the social entrepreneurs are managed to solve problems that they have personally experienced and able to inspire others. The social entrepreneurship activities also foster people with disabilities to achieve self-reliance.

\section{SPECIAL SOCIAL ENTREPRENEUR @HIGHER EDUCATION (SSEHE) PROGRAMME IN MALAYSIA}

Special Social Entrepreneur @Higher Education (SSEHE) is a programme started and mastered by Associate Professor Dr. Mass Hareeza Ali, the director of Centre Of Entrepreneurial Development and Graduate Marketability of Universiti Putra Malaysia (UPM). SSEHE is a programme developed to help Malaysian disabled youths to get exposure to the knowledge of entrepreneurship in order for them to conduct their own business in the future. By having ideas of conducting a business, it is a high hope that Malaysian disable youths will be independent individuals in the future to take care of themselves and their loved ones by making their own way of living through entrepreneurship. From this programme, it is hoped that more disabled youths will have interest in creating their own business so as to support their life and their loved ones.

Among the objectives of Special Social Entrepreneur @Higher Education are:

- Transforming the mindset of the disabled youths that they can be independent by involving in entrepreneurial activities

- Introducing the basic entrepreneurial knowledge to the disabled youths

- Opening job opportunities to the disabled youths

- Helping the disabled youths to start and/or expand their business

The expected outcomes of SSEHE are:

- Creating awareness among the disable youths about the opportunities in business/entrepreneurial activities that they can take up to be their future career

- Creating entrepreneurs among disable youths so that they will become independent in the future in creating their own income to support themselves and their loved ones

- To instill entrepreneurial spirits among the disabled youths so that they will be among others to create for the economic development of the nation

Associate Professor Dr Mass Hareeza Ali received a grant of RM 150,000 from Malaysia Higher Education Ministry to conduct this programme with four other universities. The five universities involved are Universiti Putra Malaysia (UPM), Universiti Sains Malaysia (USM), Universiti Islam Sains Malaysia (USIM), Universiti Sultan Zainal Abidin (UNiSZA) dan Universiti Perlis Malaysia (UNIMAP). Associate Professor Dr Mass Hareeza Ali planned out what her office had to do in order to materialized this programme: 
- First, she invited the other four universities to join this programme by contacting the Entrepreneurship Centre of each of the university

- Second, when she received positive response from the universities, she called for a meeting among the directors

- Third, training of trainers (ToT) were conducted at UPM in which two officers of each university were called to join the two-day ToT programme. During the ToT, UPM as the host had disseminated information and shared knowledge of how to conduct the programme at each university

- Each university agreed to follow the developed module by UPM, that is to conduct the programme for at least 5 days, with a budget of RM25,000 for each university

- Fourth, each university selected their own dates to conduct the programme and UPM released the grant money to them.

- Fifth, each university conducted the programme for 5 days, by following the developed module during the ToT

- Finally, each university sent a report to UPM to gather the data to be sent to the Malaysia Higher Education Ministry

Table 1 below summarise the process of conducting SSEHE:

Table 1

The Process of SSEHE

\begin{tabular}{|c|c|c|}
\hline $\begin{array}{l}\text { Step } 1 \\
\text { Visits to the Disabled Youths } \\
\text { Centre in } 5 \text { states in which the } 5\end{array}$ & $\begin{array}{l}\text { Step } 2 \\
\text { TOT for officers in charge from } \\
5 \text { different universities: }\end{array}$ & $\begin{array}{l}\text { Step } 3 \\
\text { Workshop for the participants: } \\
\text { The disabled Youths: }\end{array}$ \\
\hline $\begin{array}{l}\text { Visits to the centres to get } \\
\text { information of what the centres are } \\
\text { doing }\end{array}$ & $\begin{array}{l}\text { Two officers of each five } \\
\text { universities attend ToT (training of } \\
\text { trainers) organized by UPM for } 2 \\
\text { days. } \\
\text { Activities conducted: } \\
\text { Discussions on activities to be } \\
\text { conducted } \\
\text { Lecture on general knowledge on } \\
\text { disabled youths } \\
\text { Lecture on general knowledge in } \\
\text { conducting business }\end{array}$ & $\begin{array}{l}\text { Workshop for participants of the } \\
\text { disabled youths is conducted at } \\
\text { each university. } \\
\text { The modules involved: } \\
\text { Module 1: Ice breaking seesion } \\
\text { Module 2: Basic knowledge of } \\
\text { starting a business } \\
\text { Module 3: Creative marketing } \\
\text { Module 4: Financial management } \\
\text { Module 5: Presentation and Poster } \\
\text { competition among the groups } \\
\text { *Explanation of the Modules is } \\
\text { presented in Table } 2\end{array}$ \\
\hline
\end{tabular}

Table 2 below explains in details the activities of the five modules developed for SSEHE.

Table 2

The Five Developed Modules for SSEHE

\begin{tabular}{|l|l|l|}
\hline Module & Session & Activities \\
\hline Module 1 & Ice breaking session & $\begin{array}{l}\text { The module's objectives are: } \\
\text { 1. Forming identity among the young efforts towards doing } \\
\text { small business }\end{array}$ \\
& & $\begin{array}{l}\text { 2. Develop entrepreneurial spirit to be more creative and } \\
\text { innovative in carrying out business activities for young people } \\
\text { with disabilities } \\
\text { 3. Explain the importance of teamwork for to produce more } \\
\text { efficient output }\end{array}$ \\
\hline Module 2 & $\begin{array}{l}\text { Basic knowledge of starting a a } \\
\text { business }\end{array}$ & $\begin{array}{l}\text { The objectives are: } \\
\text { 1. Introduce the basics before starting a business } \\
\text { 2. Explain the importance of location selection and the } \\
\text { importance of each product or service's uniqueness } \\
\text { 3. Explain the importance of effective communication in } \\
\text { business to produce more efficient output }\end{array}$ \\
\hline
\end{tabular}




\begin{tabular}{|l|l|l|}
\hline Module 3 & Creative marketing & $\begin{array}{l}\text { This module will introduce the marketing basics for small } \\
\text { businesses. The module's objectives are to: } \\
\text { 1. Introduce some basic concepts in marketing: customer } \\
\text { targeting, consumer demand, promotion and sales } \\
\text { 2. Introduce some popular marketing tactics for small } \\
\text { businesses: sales promotion, packaging, advertising }\end{array}$ \\
\hline Module 4 & Financial management & $\begin{array}{l}\text { This module will introduce the fundamentals of financial } \\
\text { management for small businesses. The objectives of the } \\
\text { module are to: } \\
1 . \text { Introduce several basic concepts in finance: capital gains, } \\
\text { asset purchases, cost of business expenses and business } \\
\text { profitability. } \\
\text { 2. Introduce some cash flow buying and selling tactics for } \\
\text { small businesses: identify costs in sales and calculate profit and } \\
\text { loss in business }\end{array}$ \\
\hline Module 5 & $\begin{array}{l}\text { Presentation and Poster } \\
\text { competition among the groups } \\
\text { 1.To get thes articipants together and create great team work } \\
\text { among each other } \\
\text { 2. To collect their ideas and give some suggestions on how they } \\
\text { can improve them } \\
\text { 3. To choose the workable projects for them to start/improve } \\
\text { their business }\end{array}$ \\
\hline
\end{tabular}

\section{SSEHE Conducted at USM}

USM under EPIC@USM (Entrepreneurship Centre of USM) was in charge of conducting the workshop for the selected centres of disabled youths in Penang, Malaysia. EPIC@USM has chosen five disabled youth centres and USM disabled students to be among the groups of participants. The five centres are:

\begin{tabular}{|l|l|}
\hline Centre & Activities \\
\hline Care Centre of Permatang Damar Laut & Taking orders to produce paper files \\
\hline Care Centre of Air Putih & Making batik frame for artwork \\
\hline Care Centre of Sungai Tiram & Patchwork to produce foot mat \\
\hline Care Centre of Teluk Bahang & Planting vegetables and decoration plants \\
\hline Care Centre of Sungai Batu & Baking and producing snacks and tit-bits \\
\hline USM disabled students & Various activities such as book marks \\
\hline
\end{tabular}

Each centre sent seven participants and accompanied by two teachers during the five-day workshop. USM was presented by 6 disable students. All the participants followed all the five modules. The presenters of each module were briefed by EPIC@USM on how to conduct the sessions because the participants require different needs. In order to make the sessions alive, music and games were prepared so as to keep the participants awake and into the mood. There were challenges for the presenters because these disabled participants are different. The presenters need to tackle the situations when participants were bored and not able to follow the sessions.

During the workshop, the disable youths follow:

- Classes and lecture on the topic of the modules

- Conducting team work activities

- Activities to create interest in creating new business/expanding their business

- Make a poster to show their activities and future plan for their Care Centre and their own business

On the fifth day of the workshop, the participants made a presentation to show case their innovative plans on how they are going to sustain their current activities and also of what they are going to do next for their future. During the presentations, there were a few judges who made comments and gave suggestions on how to improve their business plan. 
Follow up about the participants' business activities and plans will be conducted by EPIC@USM from time to time.

\section{CONCLUSION}

Social entrepreneur is a way of business that can help disables to move forward with their life. The disables who are self-trained or followed training to prepare themselves with skills will take this opportunities to make use of their skills as a way of living. It is highly hoped that Special Social Entrepreneur @Higher Education will create awareness and interest among disabled youths to engage in business activities by using the skills that they have. In running business, the outmost outcomes is that disable youths make their own living and be independent in the later of their life.

\section{REFFERENCES}

Adib, M., \& Muin, A. (2014). Kajian Usahawan Berjaya Dalam Konteks Keusahawanan Sosial Islam: Analisis Isu dan Limitasi Kajian. 978-983.

Adib, M., Muin, A., Fakhirin, M., \& Majid, C. (2014). Model on Social Entrepreneurship: Identify the Research Gap based on Islamic Perspective.

Alter K. (2007). Social Enterprise Typology. Virtue Ventures LLC.

Austin J., Stevenson H. \& Wei-Skillern J. (2006). Social and Commercial Entrepreneurship: Same, Different, or Both? Entrep Theory Pract 30. 1-22.

Barki, E., Comini, G., Cunliffe, A., Hart, S. \& Rai, S. (2015). Social Entrepreneurship and Social Business:

Retrospective and prospective research. RAE - Revista de Administração de $\quad$ Empresas 55 (4).380 -384. Blanck P, Clay L, Schmeling J, Morris M \& Ritchie H. (2002). Applicability of the ADA to Ticket to

Work Employment Networks. Behavioral Sciences \& the Law 20. 621-36.

Blanck P, Sandler LA, Schmeling JL \& Schartz HA. 2000. The Emerging Workforce of Entrepreneurs with Disabilities: Preliminary Study of Entrepreneurship in Iowa. Iowa Law Review 85. 5.

British Council Malaysia (2019). The State of Social Enterprise in Malaysia 2018.

Carraher, S.M., \& Welsh, D.H.B. (2015). Global entrepreneurship (2nd ed.). Dubuque: Iowa.

Hao Jiao (2011). A Conceptual Model for Social Entrepreneurship Directed Toward Social Impact on Society. Social Enterprise Journal Vol. 7(2).130-149.

Mair, J. \& Martı', I. (2006). Social Entrepreneurship Research: A Source of Explanation, Prediction and Delight. Journal of World Business, Vol. 41 (1). 36-44.

Mair, J., \& Noboa, E. (2006). Social Entrepreneurship: How Intentions to Create a Social Venture Get Formed. In J. Mair, J. Robinson, \& K. Hockerts (Eds.), Social Entrepreneurship: 121- 136. New York:

M. Yunus, B. Moingeon \& L. Lehmann-Ortega (2010). Long Range Planning, 43(2-3). 308-

325.

OECD (2003b) Entrepreneurship and Local Economic Development. Paris: OECD.

Reid A. 2004 Social Entrepreneurs: A New Brand of Disability-Rights Activists. In: Disability World.

Ricketts, M. (2008). Theories of Entrepreneurship: Historical Development and Critical Assessment. In M. Casson, B. Yeung, A. Basu, \& N. Wadeson (Eds.), The Oxford handbook of entrepreneurship (33-58). Oxford: Oxford University Press.

Roberts, D. \& Woods, C. (2005). Changing the World on A Shoestring: The Concept of Social Entrepreneurship. University of Auckland Business Review, Vol. 19 (1). 45-51.

Saifuddin Abdullah. (2012). "Keusahawanan Sosial Basmi Kemiskinan”. Akhbar Sinar Harian.

Saifuddin Abdullah. (2009). "Keusahawanan Sosial Dalam Penyelidikan”. Akhbar Utusan Malaysia. 
S.L. Khoo, L. Tiun, \& L.W. Lee (2013). Kajian Malaysia, 31(1).

Shane, S., \& Venkataraman, S. (2000). The Promise of Entrepreneurship as A Field of Research. Journal of Management, 25(1), 217-226.

Shaw E. \& Carter S. (2007). Social Entrepreneurship: Theoretical Antecedents and Empirical Analysis of Entrepreneurial Processes and Outcomes. Journal of Small Business and Enterprise Development 14. 418-34.

Si, S., Yu, X., Wu, A., Chen, S., Chen, S., \& Su, Y. (2015). Entrepreneurship and Poverty Reduction: A Case Study of Yiwu, China. Asia Pacific Journal of Management, 32.119-143.

S.T. Certo, T. Miller (2008).Social Entrepreneurship: Key Issues and Concepts. Business Horizons, 51(4). 267271.

Thake, S., \& Zadek, S. (1997). Practical People, Noble Causes. How to Support Community Based Social Entrepreneurs. London: New Economics Foundation.

Zahra S. A., Gedajlovic E, Neubaum DO \& Shulman JM. (2009). A Typology of Social Entrepreneurs: Motives, Search Processes and Ethical Challenges. Journal of Business Venturing 24. 519-32

Zahra S.A., H. Rowhouser, N. Bhawe, D. Neubaum, \& J. Hayton (2008). Strategic Entrepreneurship Journal, 2(2).117-131. 